\section{Discussion}

The trial has shown that compound 1003 will lower the blood-pressure in severe and moderately severe hypertensives to a good level of control in $58 \%$ and to a moderate level of control in $34 \% ; 8 \%$ remain poorly controlled. Not enough mild hypertensives have been treated to comment on these. The response in the renal and malignant hypertensives is good.

No significant rise in the blood urea occurred during treatment with 1003 alone, although, as with other hypotensive drugs, there was often a rise on adding polythiazide, which in some cases returned to previous levels, but in others remained elevated.

Clinically, the actions and side-effects of 1003 are similar to -those of guanethidine, but in some cases it has proved effective where guanethidine has failed, and in others has produced fewer side-effects.

In $64 \%$ of the out-patients polythiazide was given in addition to 1003 to help control ; this figure is similar in our experience to that in treatment with guanethidine and methyldopa.

Lack of energy was the most troublesome side-effect ; diarrhoea was also common initially, but was easily controlled with codeine phosphate and usually wore off with continued treatment. Postural and exertional dizziness and sexual symptoms occurred about as often as in guanethidine therapy. Nausea was troublesome in some patients but in only one case did the treatment have to be stopped because of it.

There were two certain cases of drug reaction and a probable third out of 62 cases assessed. However, symptoms quickly settled on withdrawing the drug.

The action of compound 1003 in depleting the hypothalamus and the adrenal medulla of pressor amines led us to look for any obvious differences from guanethidine in its mode of action in the clinical control of patients with hypertension ; we found no very apparent difference, but attempts to correlate action in a particular area in the animal with the effect of lowering the blood-pressure in man are extremely difficult. At present this applies to most drugs used in the treatment of hypertension, since it is by no means clear which of their many pharmacological actions is responsible for lowering the blood-pressure.

Compound 1003 has been shown to be a suitable drug for the treatment of patients with hypertension of moderate or severe degrees, whether associated with renal disease or not.

\section{Summary}

A trial is reported of a new hypotensive compound 1003 (" envacar"). In 62 cases it has been shown to provide good control in $58 \%$, moderate control in $34 \%$, and poor control in $8 \%$.

Most of the patients had severe hypertension, $50 \%$ had diastolic pressures of more than $140 \mathrm{~mm}$., and $48 \%$ between 120 and $140 \mathrm{~mm}$. The drug is effective in malignant hypertension and in hypertension associated with renal disease. In some cases it has been effective where other drugs have failed. Side-effects include lethargy, nausea, and diarrhoea.

Our thanks are due to Pfizer Limited, Sandwich, Kent, for · supplies of compound 1003.

\section{REFERENCES}

Dollery, C. T., Emslie-Smith, D., and Milne, M. D. (1960). Ibid., 2, 381

Bayliss, R. I. S., and Harvey-Smith, E. A. (1962). Lancet, 1, 763.

\title{
Clinical Trial and Pharmacological Study of Compound 1029 ("Vatensol ")
}

\author{
T. D. V. LAWRIE,* M.D., B.SC., M.R.C.P.GLASG., M.R.C.P.ED. ; A. R. LORIMER,* M.B., CH.B. \\ S. G. MCALPINE, $\dagger$ M.D., M.R.C.P., M.R.C.P.GLASG. ; H. REINERT, $\ddagger$ M.D.
}

Brit. med. 9., 1964, 1, 402-406

Although the role of noradrenaline in the causation and maintenance of hypertension has not yet been clearly established a number of anti-hypertensive drugs directly affect adrenergic mechanisms, the pharmacological actions being direct antagonism and effects on the storage, release, or synthesis of the transmitter.

This paper describes a clinical and pharmacological study of a new anti-hypertensive agent developed by Pfizer Ltd. (U.K.). This compound, designated 1029 , is [ (2-(2, 6-dichlorophenoxy) ethyl) aminol guanidine sulphate ("vatensol "), which has been shown to have the following pharmacological actions: (1) inhibition of dopamine beta-oxidase, (2) adrenergic neurone blockade, (3) depletion of noradrenaline in the C.N.S., and (4) depletion of peripheral tissue noradrenaline. In the adrenal medulla there was depletion of noradrenaline and, to a larger extent, adrenaline.

* Royal Infirmary, Glasgow. † Royal Alexandra Infirmary, Paisley. ‡ Department of Pharmacology, Pfizer Ltd., Sandwich.

\section{Animal Pharmacology}

The anti-hypertensive effect and modes of action of compound 1029 were demonstrated in animals and in vitro by the following experiments :

(a) Repeated oral administration of $1029(20 \mathrm{mg} . / \mathrm{kg}$., per os, for three days) to beagle dogs with experimentally induced nephrogenic or neurogenic hypertension produced a sustained anti-hypertensive effect, reduced the tyramine pressor response, and increased the dimethyl-phenyl piperazinieum and noradrenaline pressor responses in the non-anaesthetized dog.

(b) Adrenergic Neurone Blockade.-(1) Abolition of the response of the nictitating membrane to pre- and post-ganglionic stimulation in the anaesthetized cat. (2) Inhibition of release of noradrenaline from the spleen on electrical stimulation of the splenic nerve. (3) Reduction of the pressor response to injected tyramine and splenicnerve stimulation, without effect on pressor response to injected adrenaline and noradrenaline.

(c) Amine Depletion.-The noradrenaline content of heart, spleen, and hypothalamus, and the content of adrenaline and nor- 
adrenaline of the adrenals were reduced, following oral administration of 1029 (10 and $40 \mathrm{mg} . / \mathrm{kg}$.) for six weeks to beagle dogs. Catecholamines estimated by the method described by Merrills $(1962,1963)$. Single doses did not affect amine levels in rats, but daily intraperitoneal injections for three weeks (20 mg. $/ \mathrm{kg}$.) produced a significant fall in adrenal catecholamines only.

(d) Enzyme Inhibition.-(1) 1029, at a concentration of $9 \times 10^{-5} \mathrm{M}$, inhibited dopamine beta-oxidase by $50 \%$. Dopamine beta-oxidase was prepared from bovine adrenals by the method described by Levine et al. (1960) but using catalase instead of adenosine triphosphate. In the same preparation the amount of noradrenaline synthesized after incubation with 1029 and other compounds was determined, and the results are shown in Table I. These experiments demonstrated that 1029 had a greater inhibitory activity on dopamine beta-oxidase than the inhibitor benzyloxamine examined by Crevelling et al. (1962). (2) 1029 was administered to beagle dogs for four months (10 mg. $/ \mathrm{kg}$. per os), at the end of which time 24-hour specimens of urine were analysed for noradrenaline.

TABLE I

\begin{tabular}{|c|c|c|}
\hline \multirow{2}{*}{ Concentration of compound : } & \multicolumn{2}{|c|}{$\begin{array}{c}\text { Percentage Inhibition } \\
\text { Noradrenaline Synthesis }\end{array}$} \\
\hline & $.5 \times 10^{-6}$ & $1 \times 10^{-6}$ \\
\hline 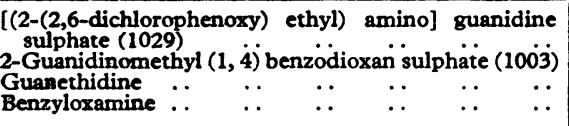 & $\begin{array}{r}80 \cdot 8 \\
0 \\
9 \cdot 1 \\
64 \cdot 4\end{array}$ & $\frac{41 \cdot 2}{33 \cdot 9}$ \\
\hline
\end{tabular}

As 1029 has adrenergic neurone-blocking properties any reduction in urinary noradrenaline could possibly be due to a decrease in the release of the amines from adrenergic nerveendings. For this reason, noradrenaline estimations were also made on urines from dogs treated for nine months with the adrenergic blocking agent 1003 ("envacar"), which is a more potent adrenergic neurone-blocking and amine-depleting agent than 1029.

Results are given in the Chart, which also includes urines from untreated control animals. As can be seen, the noradrenaline output was effectively reduced by 1029 only. These results therefore suggest to us that 1029 inhibits dopamine betaoxidase in vivo. Thus compound 1029 possesses a novel combination of pharmacological actions, and it was thought of interest to investigate its effect in patients with hypertension.
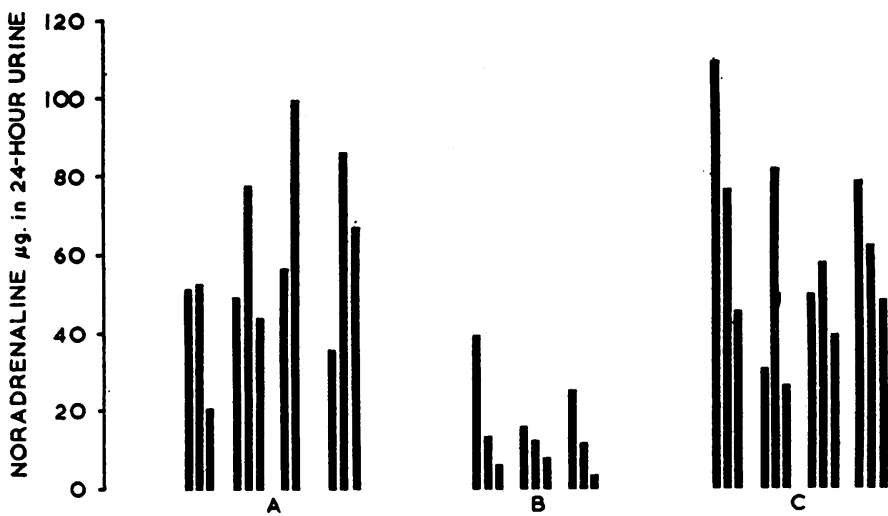

Beagle dogs. Ordinates: $\mu$ g. noradrenaline in 24-hour urine. Histograms show noradrenaline values collected on three consecutive days; each group in $A, B$, and $C$ represents the results from one beagle dog. A: Untreated controls. B: After four months' treatment with $10 \mathrm{mg} . /$ kg. 1029 per os daily. C: After nine months' treatment with $40 \mathrm{mg} . / \mathrm{kg}$. 1003 per os daily.

\section{Clinical Studies}

Thirty-nine patients were treated for periods ranging from 1 to 11 months (Table II). Their age and sex distribution are shown in Table III.

For the purpose of this study all patients were classified according to the severity of the hypertension (Table IV), employ- ing the following definitions: (1) Mild=diastolic bloodpressure from 95 to $110 \mathrm{~mm} . / \mathrm{Hg}$; (2) Moderate=diastolic blood-pressure from 111 to $125 \mathrm{~mm} . / \mathrm{Hg}$; (3) Severe $=$ diastolic blood-pressure from 126 to $140 \mathrm{~mm} . / \mathrm{Hg}$; (4) Gross $=$ diastolic blood-pressure above $140 \mathrm{~mm} . / \mathrm{Hg}$.

TABLE II.-Duration of Treatment

\begin{tabular}{|c|c|c|c|c|c|c|}
\hline \multicolumn{4}{|c|}{ Duration } & \multirow{2}{*}{$\begin{array}{c}\text { Males } \\
1 \\
3 \\
6 \\
9 \\
3\end{array}$} & \multirow{2}{*}{$\begin{array}{c}\text { Females } \\
\overline{3} \\
8 \\
4 \\
2\end{array}$} & \multirow{2}{*}{$\begin{array}{r}\text { Total } \\
1 \\
6 \\
14 \\
13 \\
5\end{array}$} \\
\hline $\begin{array}{l}\text { Under } 1 \text { month } \\
1 \text { to } 3 \text { months } . . \\
3 \text { to } 6 \text { months } . . \\
6 \text { to } 9 \text { months .. } \\
\text { Over } 9 \text { months }\end{array}$ & $\begin{array}{l}. . \\
\therefore \\
\therefore\end{array}$ & $\begin{array}{l}\because \\
\because \\
\because\end{array}$ & $\begin{array}{l}\ddot{ } \\
\ddot{0} \\
\therefore\end{array}$ & & & \\
\hline
\end{tabular}

TABLE III.-Age and Sex Distribution

\begin{tabular}{|c|c|c|c|c|c|c|c|}
\hline \multicolumn{5}{|c|}{ Age in Years } & \multirow{2}{*}{$\begin{array}{c}\text { Male } \\
2 \\
5 \\
11 \\
4\end{array}$} & \multirow{2}{*}{$\begin{array}{c}\text { Female } \\
3 \\
5 \\
7 \\
2 \\
\end{array}$} & \multirow{2}{*}{$\begin{array}{c}\text { Total } \\
5 \\
10 \\
18 \\
6\end{array}$} \\
\hline $\begin{array}{l}30-39 \\
40-49 \\
50-59 \\
60-69 \\
\end{array}$ & $\begin{array}{l}. \\
\because \\
\cdots\end{array}$ & $\begin{array}{l}. \\
\because \\
.\end{array}$ & $\begin{array}{l}\cdots \\
\cdots \\
\cdots\end{array}$ & $\begin{array}{l}. \\
\therefore \\
\therefore \\
\end{array}$ & & & \\
\hline & Total & .. & $\ldots$ & $\ldots$ & 22 & 17 & 39 \\
\hline
\end{tabular}

TABLE IV.-Severity of Hypertension

\begin{tabular}{|c|c|c|c|c|c|c|c|}
\hline \multicolumn{5}{|c|}{ Severity } & \multirow{2}{*}{ 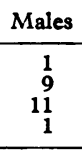 } & \multirow{2}{*}{$\begin{array}{c}\text { Females } \\
-4 \\
8 \\
5\end{array}$} & \multirow{2}{*}{$\begin{array}{r}\text { Total } \\
1 \\
13 \\
19 \\
6\end{array}$} \\
\hline $\begin{array}{l}\text { Mild .. } \\
\text { Moderate } \\
\text { Severe } \quad . . \\
\text { Gross } \quad . .\end{array}$ & $\begin{array}{l}\cdots \\
\cdots \\
\cdots\end{array}$ & $\begin{array}{l}\cdots \\
\cdots \\
\cdots\end{array}$ & $\begin{array}{l}\cdots \\
\cdots \\
\cdots\end{array}$ & $\begin{array}{l}. \\
\cdots \\
\cdots\end{array}$ & & & \\
\hline Total & $\cdots$ & .. & $\cdots$ & .. & 22 & 17 & 39 \\
\hline
\end{tabular}

The retinal changes (Table $\mathrm{V}$ ) were graded according to the method of Keith et al. (1939).

Twenty-three cases had previously received one or more of the following anti-hypertensive drugs-pentolinium, rauwolfia, mecamylamine, bretylium, guanethidine, and methyldopa ; in all of these cases therapy had been discontinued because of lack of control of blood-pressure and/or unacceptable side-effects. The remaining 16 had not received any previous treatment.

\begin{tabular}{|c|c|c|c|c|c|c|c|}
\hline \multicolumn{5}{|c|}{ Retinal Grade } & \multirow{2}{*}{$\begin{array}{c}\text { Idiopathic } \\
\overline{23} \\
3 \\
3\end{array}$} & \multirow{2}{*}{$\begin{array}{c}\text { Renal } \\
1 \\
5 \\
4 \\
-\end{array}$} & \multirow{2}{*}{$\begin{array}{c}\text { Total } \\
\begin{array}{r}1 \\
28 \\
7 \\
3\end{array}\end{array}$} \\
\hline $\begin{array}{l}\text { O-I } \\
\text { II } \\
\text { III } \\
\text { IV }\end{array}$ & $\begin{array}{l}\because \\
\because\end{array}$ & 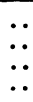 & $\begin{array}{l}\ddot{ } \\
\ddot{0}\end{array}$ & 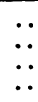 & & & \\
\hline & & & & & 29 & 10 & 39 \\
\hline
\end{tabular}

\section{Regimen of Administration}

In all cases the drug was administered orally, and its effects were studied after single doses and on continuous therapy.

\section{A. Single Doses}

In an attempt to determine the time of onset and duration of hypotensive effect, four patients were given single doses and the blood-pressure was recorded hourly for the next 12 hours. In the mild and moderate groups of hypertensives the initial dose was $25 \mathrm{mg}$. and in the severe group $50 \mathrm{mg}$. If no response was obtained, $50 \mathrm{mg}$. and $75 \mathrm{mg}$. respectively were administered two days later, the blood-pressure being recorded as before. If a response was still not obtained the doses were increased to $75 \mathrm{mg}$. and $100 \mathrm{mg}$. respectively two days later. Placebos were also given and the effects compared.

\section{B. Continuous Therapy}

In the initial stages of the investigation, before average dose requirements had been determined, treatment was started at 
$5 \mathrm{mg}$. b.i.d. and increased every second day by $10 \mathrm{mg}$. daily until an adequate response was obtained, or until a total daily dose of $80 \mathrm{mg}$. had been reached. If no response was obtained at this dosage an oral diuretic, polythiazide, was added thrice weekly, $1 \mathrm{mg}$. per dose.

In the later stages of the investigation two changes were made in the treatment regime: (a) the upper limit of dosage at which a diuretic was added was raised from 80 to $100 \mathrm{mg}$./day, and (b) the initial daily dosage was raised from 10 to $20 \mathrm{mg}$. The average daily dose was approximately $100 \mathrm{mg}$. given in two or three divided doses. The lowest daily dose on which a response was obtained was $50 \mathrm{mg}$. ; the highest daily dose administered to date has been $300 \mathrm{mg}$.

In-patient treatment differed from that of out-patients in that the daily dosage was raised by $20 \mathrm{mg}$. on alternate days in the former group and by $10 \mathrm{mg}$. a day at intervals which were not more frequent than twice weekly in the latter. Bloodpressures were recorded in the lying and standing positions at the same time each day in both in-patients and out-patients. Before treatment, and at frequent intervals throughout treatment, blood counts, serum electrolyte, and liver-function tests were carried out.

For the purpose of catecholamine studies 24-hour specimens of urine were collected from 11 of the patients included in this trial (eight with severe, two with moderate, and one with malignant hypertension). One or two pretreatment specimens were obtained. For purposes of comparison urines were also collected from four patients who were being treated with guanethidine, and the results are given in Table VIII. These samples were analysed for noradrenaline by the method described above.

\section{Results}

Single Doses.-The earliest fall in blood-pressure was seen at three to four hours, was maximal at six to eight hours, and lasted approximately 12 hours. When the drug was given on consecutive rather than on alternate days the impression was gained that the action was cumulative.

Continuous Therapy.-The criterion for satisfactory response to therapy was a sustained fall in diastolic blood-pressure to 95-100 mm./Hg in either the erect or supine position.

\section{Idiopathic and Renal Hypertension}

A total of 36 patients were treated with 1029 alone, the results being given in Table VI. Twenty-three responded to treatment. Of these, 3 had gross, 12 severe, 7 moderate, and 1 mild hypertension. The remaining 13 failed to respond to 1029 alone, but of these four with moderate idiopathic hypertension were treated in the early part of the investigation with doses which we do not now regard as adequate $(60 \mathrm{mg}$. daily). Of the other nine patients, three were withdrawn from the trial ; the first, a female with moderate renal hypertension, did

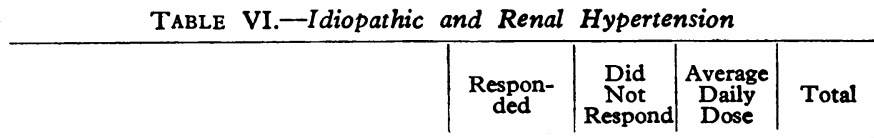

\begin{tabular}{|c|c|c|c|c|c|c|c|c|}
\hline \multicolumn{9}{|c|}{ Idiopathic Group } \\
\hline Males & $\left\{\begin{array}{l}\text { Previous } \\
\text { No prev }\end{array}\right.$ & $\begin{array}{l}\text { rapy } \\
\text { therapy }\end{array}$ & & 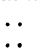 & $\begin{array}{l}4 \\
6\end{array}$ & $\begin{array}{l}4 \\
2\end{array}$ & $\begin{array}{l}85 \\
70\end{array}$ & $\begin{array}{l}8 \\
8\end{array}$ \\
\hline \multirow[t]{2}{*}{ Females } & $\left\{\begin{array}{l}\text { Previous } \\
\text { No prev }\end{array}\right.$ & $\begin{array}{l}\text { rapy } \\
\text { therapy }\end{array}$ & & $\therefore$ & $\begin{array}{l}5 \\
2\end{array}$ & $\begin{array}{l}2 \\
1\end{array}$ & $\begin{array}{l}70 \\
55\end{array}$ & $\begin{array}{l}7 \\
3\end{array}$ \\
\hline & Total & . & .. & .. & 17 & 9 & - & 26 \\
\hline \multicolumn{9}{|c|}{ Renal Group } \\
\hline Males & $\left\{\begin{array}{l}\text { Previous } \\
\text { No prev }\end{array}\right.$ & 3 therapy & & $\because$ & $\begin{array}{l}0 \\
3\end{array}$ & $\begin{array}{l}2 \\
0\end{array}$ & $\begin{array}{l}60 \\
60\end{array}$ & $\begin{array}{l}2 \\
3\end{array}$ \\
\hline \multirow[t]{2}{*}{ Females } & $\left\{\begin{array}{l}\text { Previous } \\
\text { No prev }\end{array}\right.$ & $\begin{array}{l}\text { rapy } \\
\text { therapy }\end{array}$ & & $\because$ & $\begin{array}{l}2 \\
1\end{array}$ & $\begin{array}{l}1 \\
1\end{array}$ & $\begin{array}{r}90 \\
120\end{array}$ & $\begin{array}{l}3 \\
2\end{array}$ \\
\hline & Total & .. & . & .. & 6 & 4 & - & 10 \\
\hline
\end{tabular}

not respond to 1029 , but complained of postural giddiness. The second, a female with moderate idiopathic hypertension, demonstrated a transient fall in pressure but subsequently complained of postural giddiness and demonstrated an increase in blood-pressure. The third, a male with severe idiopathic hypertension, developed an urticarial rash which was similar to a rash he had developed while being treated with methyldopa. The remaining six patients were suffering from severe or gross idiopathic hypertension.

These 10 failures were then treated with a combination of 1029 plus the thiazide diuretic polythiazide (" nephril"), at a dose of $1 \mathrm{mg}$. thrice weekly ; and seven responded to this combination therapy. Thus out of 36 patients with idiopathic or renal hypertension 30 were controlled with either 1029 alone or with a combination of 1029 and polythiazide.

\section{Malignant Hypertension}

Three patients with malignant hypertension (presence of Grade IV fundi) who had failed previously on anti-hypertensive therapy were admitted to the trial. Of these, one male and one female responded to treatment with 1029 alone. In the male the response was not maintained; in the female, after 10 days' treatment with the dose which controlled her bloodpressure, there was severe postural hypotension. The third patient failed to show any response. The first and third of these patients were then treated with the combination of 1029 and polythiazide and both responded, their papilloedema resolving. The second patient has not yet been treated with the combination.

\section{Effect of Addition of a Diuretic (Polythiazide)}

In five patients who were well controlled on 1029 alone, the effect of the addition of polythiazide ( $1 \mathrm{mg}$. thrice weekly) was studied. It was noted that the dosage of 1029 could be reduced by approximately $50 \%$.

In one patient who had normal blood urea and blood $\mathrm{pH}$ a low serum potassium ( $3.3 \mathrm{mEq} / 1$.) was observed, but after oral administration of effervescent potassium chloride normal values were obtained.

\section{Comparison with Previous Treatment}

Ten patients-eight with idiopathic, one with renal, and one with malignant hypertension-had previously been treated with methyldopa. In none of these had the response been satisfactory, being either poor, absent altogether, or associated with severe side-effects. Five of these responded to 1029 alone, although in one, a female with malignant hypertension, this response was associated with a severe postural hypotension. One demonstrated a good response to the combination of 1029 and polythiazide. Four failed to respond to 1029-three with severe and one with gross idiopathic hypertension. No data are available on the effect of methyldopa in patients who failed to respond to 1029 or the combination of 1029 and polythiazide.

Eight patients had previously been treated with guanethidine with a similar unsatisfactory response. Of these, three responded to 1029 alone and two, both with malignant hypertension, responded to a combination of 1029 and polythiazide. The remaining three failed to respond to 1029 or the combination of 1029 and polythiazide.

\section{Side-effects}

Side-effects were recorded in 14 patients: postural giddiness in 9, muscular weakness and tiredness in 4, skin rash in 1, 
failure of erection in 1 , failure of ejaculation in 3 , headaches in 2 , drowsiness in 1 , and gastro-intestinal in 2 .

Of the nine patients who exhibited postural giddiness, two had transient loss of consciousness and two had increased giddiness with blurring of vision, when attempting moderate exertion. In these patients the impression was gained that when polythiazide was added the side-effects became less severe and the patients more comfortable without impairment of their blood-pressure control.

The gastro-intestinal symptoms consisted of vague abdominal discomfort, but this symptom had been produced when taking various other drugs. Looseness of the bowels was encountered in one patient but was not severe enough to stop treatment. Failure of ejaculation had also been noted in one case on guanethidine therapy.

Troublesome tachycardia has not yet been noted.

Liver-function tests (serum proteins, serum bilirubin, thymol turbidity, and alkaline phosphatase) have remained within normal limits.

Four patients were withdrawn from the trial. The first was withdrawn because of increasing uraemia, this patient having an initial blood urea of $100 \mathrm{mg} . / 100 \mathrm{ml}$. and suffering from bilateral pyelonephritis. Despite the rising blood urea his bloodpressure was well-controlled by 1029 . The second patient developed urticaria, which, as already stated, also developed while on treatment with methyldopa. The third and fourth patients have already been described and complained of postural giddiness with 1029.

Three patients died during the course of the trial, one from chronic pyelonephritis, this being the patient mentioned in the section above, one from polyarteritis nodosa, and the third from lymphosarcoma.

Compound 1029 was also given for a short time to four patients who have not been included in the analyses. The first was a female who had vestibular damage after streptomycin therapy, and who experienced left-sided weakness whenever there was a slight reduction in her diastolic blood-pressure. The second was a male who had an acute exacerbation of chronic bronchitis and was thus unable to attend the clinic. The third was a female who suffered a subarachnoid haemorrhage after only a short period on the trial. The fourth was a female who complained of multiple subjective symptoms while on both 1029 ( $5 \mathrm{mg}$.) and a placebo and with whom there was some doubt whether the tablets were being taken.

\section{Nitrogen Retention}

Before treatment started, 16 patients ( 7 with idiopathic, 7 with renal, and 2 with malignant hypertension) had blood ureas above $40 \mathrm{mg} . / 100 \mathrm{ml}$. During treatment with 1029 or the combination of 1029 and polythiazide the blood ureas fell in three of these patients (two idiopathic and the one malignant hypertensive); it remained stationary in the remaining five patients with idiopathic hypertension and in four with renal hypertension. It rose further in three patients with renal hypertension and in one with malignant hypertension. One renal hypertensive patient with chronic pyelonephritis later died of uraemia.

Six of the patients with idiopathic hypertension whose initial blood urea was below $40 \mathrm{mg} . / 100 \mathrm{ml}$. demonstrated a rise in blood urea during treatment. The average rise (above the initial level) was $23 \mathrm{mg}$. and the highest level reached was $61 \mathrm{mg}$. In four of these, including the patient with the high level, the rise was transient.

\section{Catecholamines}

The results of the noradrenaline estimations on the 24-hour specimens of urine are given in Table VII for the 11 patients receiving 1029 and in Table VIII for the patients receiving guanethidine.

TABLE VII.-Correlation of Urinary Noradrenaline with Standing Diastolic Blood-pressure in Patients Treated with Compound 1029

\begin{tabular}{|c|c|c|c|c|c|c|c|c|c|c|c|c|c|c|c|c|c|}
\hline Date (1963) & \multicolumn{2}{|c|}{ Case 1} & \multicolumn{3}{|c|}{ Case 2} & \multicolumn{4}{|c|}{ Case 3} & \multicolumn{3}{|c|}{ Case 4} & \multicolumn{5}{|c|}{ Case 5} \\
\hline \multirow[t]{2}{*}{ 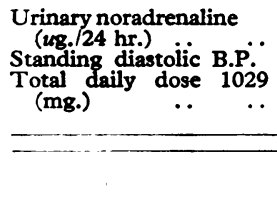 } & $\begin{array}{l}108 \\
130 \\
\text { Pre }\end{array}$ & $\begin{array}{c}79 \cdot 3 \\
105 \\
20\end{array}$ & $\begin{array}{r}82 \\
115 \\
\text { Pre }\end{array}$ & $\begin{array}{r}34.7 \\
100 \\
70\end{array}$ & $\begin{array}{c}24 \cdot 6 \\
95 \\
70\end{array}$ & $\begin{array}{l}48 \cdot 3 \\
120 \\
\text { Pre }\end{array}$ & $\begin{array}{c}34.5 \\
100 \\
30\end{array}$ & $\begin{array}{r}23 \cdot 7 \\
100 \\
40\end{array}$ & $\begin{array}{r}15 \cdot 5 \\
80 \\
40\end{array}$ & $\begin{array}{l}140 \\
130 \\
\text { Pre }\end{array}$ & $\begin{array}{c}30.8 \\
95 \\
50\end{array}$ & $\begin{array}{l}43 \\
95 \\
60\end{array}$ & $\begin{array}{l}18 \cdot 3 \\
130 \\
\text { Pre }\end{array}$ & $\begin{array}{r}21.5 \\
120 \\
30\end{array}$ & $\begin{array}{c}26 \cdot 1 \\
105 \\
50\end{array}$ & $\begin{array}{r}72 \\
100 \\
50\end{array}$ & $\begin{array}{r}33 \\
90 \\
100\end{array}$ \\
\hline & \multicolumn{3}{|c|}{ Case 6} & \multicolumn{7}{|c|}{ Case 7} & \multicolumn{3}{|c|}{ Case 8} & \multicolumn{4}{|c|}{ Case 9} \\
\hline $\begin{array}{l}\text { Urinary noradrenaline } \\
\text { (ug./24 hr.) } \\
\text { Standing diastolic B.P. } \\
\text { Total daily dose } 1029 \\
\text { (mg.) } \\
\begin{array}{l}\text { (mg.) } \\
. .\end{array}\end{array}$ & $\begin{array}{l}10 \cdot 3 \\
130\end{array}$ & $\begin{array}{r}7.2 \\
100\end{array}$ & $\begin{array}{l}10.9 \\
110\end{array}$ & $\begin{array}{l}17.0 \\
130 \\
\text { Pre }\end{array}$ & $\begin{array}{l}19 \cdot 6 \\
130\end{array}$ & $\begin{array}{r}0 \\
90\end{array}$ & $\begin{array}{r}0 \\
120\end{array}$ & $\begin{array}{l}14 \cdot 2 \\
105\end{array}$ & $\begin{array}{l}17.9 \\
110\end{array}$ & $\begin{array}{l}18 \cdot 6 \\
140\end{array}$ & $\begin{array}{l}317 \\
140\end{array}$ & $\begin{array}{l}166 \\
120\end{array}$ & $\begin{array}{l}165 \\
115\end{array}$ & $\begin{array}{l}12 \cdot 0 \\
170 \\
\text { Pre }\end{array}$ & $\begin{array}{c}8.2 \\
140\end{array}$ & $\begin{array}{r}0 \\
100\end{array}$ & $\begin{array}{r}6.3 \\
100\end{array}$ \\
\hline
\end{tabular}

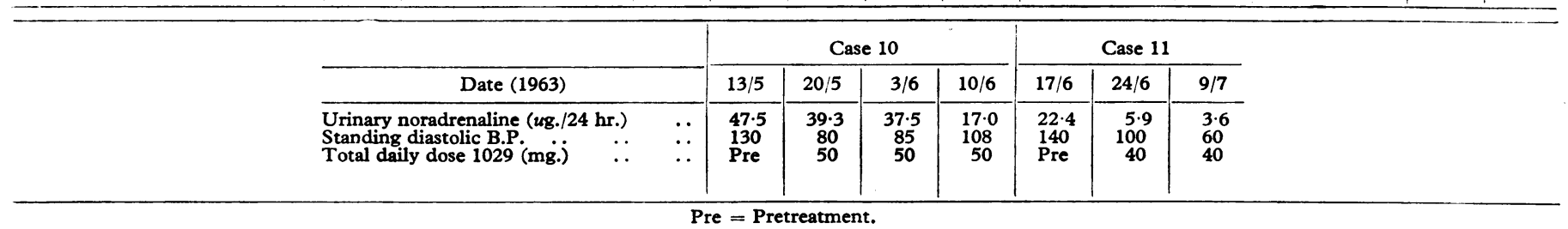

TABLE VIII.-Correlation of Urinary Noradrenaline with Standing Diastolic Blood-pressure in Patients Treated with Guanethidine

\begin{tabular}{|c|c|c|c|c|c|c|c|c|c|c|c|c|c|c|c|c|c|}
\hline \multirow[b]{2}{*}{ Date (1963) } & \multicolumn{5}{|c|}{ Case A } & \multicolumn{5}{|c|}{ Case B } & \multicolumn{5}{|c|}{ Case C } & \multicolumn{2}{|c|}{ Case $\mathbf{D}$} \\
\hline & $11 / 7$ & $22 / 7$ & 5,8 & $4 / 9$ & $10 / 9$ & $11 / 8$ & $18 / 8$ & $25 / 8$ & $1 / 9$ & $8 / 9$ & $6 / 8$ & $14 / 8$ & $21 / 8$ & 4/9 & $13 / 9$ & $1 / 9$ & 9/9 \\
\hline $\begin{array}{l}\text { Urinary noradrenaline } \\
\text { (ug./24 hr.) } \\
\text { Standing diastolic B.P. } \\
\text { Total daily dose guan- }\end{array}$ & $\begin{array}{l}46 \cdot 0 \\
140\end{array}$ & $\begin{array}{c}30 \cdot 3 \\
95\end{array}$ & $\begin{array}{l}28.4 \\
105\end{array}$ & $\begin{array}{l}32.0 \\
118\end{array}$ & $\begin{array}{l}57.5 \\
118\end{array}$ & $\begin{array}{l}54 \cdot 0 \\
120\end{array}$ & $\begin{array}{l}77.5 \\
120\end{array}$ & $\begin{array}{l}73.5 \\
100\end{array}$ & $\begin{array}{c}86 \cdot 0 \\
90\end{array}$ & $\begin{array}{l}46.0 \\
100\end{array}$ & $\begin{array}{l}51 \cdot 0 \\
124\end{array}$ & $\begin{array}{l}65.0 \\
120\end{array}$ & $\begin{array}{l}45 \cdot 0 \\
110\end{array}$ & $\begin{array}{c}50 \cdot 0 \\
96\end{array}$ & $\begin{array}{c}63 \cdot 0 \\
84\end{array}$ & $\begin{array}{l}28 \cdot 4 \\
120\end{array}$ & $\begin{array}{l}45 \cdot 0 \\
105\end{array}$ \\
\hline ethidine (mg.) .. & Pre & 30 & 25 & 40 & 40 & Pre & 30 & 60 & 60 & 60 & 10 Pre & 20 & 30 & 30 & - & Pre & 20 \\
\hline
\end{tabular}




\section{Discussion}

In the past, various criteria have been adopted to classify the response to treatment with anti-hypertensive compounds. In the present series the criterion of response has been fairly stringent (fall in diastolic blood-pressure to $100 \mathrm{~mm} . / \mathrm{Hg}$ in either the erect or supine position), particularly in respect of the patients with severe and gross hypertension.

With this criterion, compound 1029 alone was found to be effective in approximately two-thirds of the patients treated, the majority of whom had severe or gross hypertension (23 patients, of whom 12 had severe and 2 had gross hypertension). It appears to be equally effective in the idiopathic and renal groups, although the renal group was small.

Compound 1029 produced a fall in both systolic and diastolic pressures, both supine and standing, but more pronounced in the latter. As has been described only three patients were removed from the trial because of side-effects.

In one-third of the patients the blood-pressure was not controlled by compound 1029 alone. These consisted of three patients with malignant hypertension, six with severe or gross hypertension, and four with moderate hypertension in whom the dosage was inadequate. This one-third also includes the three patients from whom the drug was withdrawn. Seven patients from this group responded to the combination of 1029 and polythiazide.

In this series 23 patients had failed to respond to previous anti-hypertensive treatment ; in this instance failure includes the occurrence of severe side-effects. Ten of these had been unsuccessfully treated with methyldopa and of these four responded well to 1029 alone, one responded well to the combination of 1029 and polythiazide, and a sixth responded to 1029 but the response was associated with severe postural hypotension. Eight patients had previously been unsuccessfully treated with guanethidine and of these three responded to 1029 alone and two to the combination of 1029 and polythiazide.

The action of 1029 in combination with polythiazide is of interest in that with the combination (a) the number of failures was further reduced, seven patients responding to the combination, who had not responded to 1029 alone; $(b)$ it was possible to use a lower dosage of 1029 which resulted in (c) a decrease in the incidence and severity of side-effects.

In four patients who had been treated with 1029 for six months a gradual increase in dose was required in order to maintain control. This could, of course, be due either to the development of tolerance to the drug or to the natural progression of the underlying disease.

The effect on blood urea was variable. In the patients who demonstrated a rise their therapy had to be discontinued in one only, a man who had chronic pyelonephritis. The incidence of raised blood ureas was similar to that found in this department with other anti-hypertensive agents (Fife et al., 1962).
No other biochemical or haematological abnormalities were observed. The incidence of side-effects was low, but this may be attributable to our limited experience with the drug to date.

The examination of urines from hypertensive patients treated with 1029 shows, in the majority of cases, a decreased noradrenaline output related to a fall in blood-pressure that was not seen in patients who had been treated with guanethidine. This indicates that 1029 may have an inhibitory activity on dopamine beta-axidase in man. It is obvious, however, that further studies will have to be undertaken before this can be confirmed.

The novel mode of action that is suggested by the animal pharmacology, in vitro studies, and the clinical results indicate that 1029 is worthy of further study.

\section{Summary}

A trial is reported of a new anti-hypertensive agent, compound 1029 ("vatensol").

In 39 patients it has been demonstrated that with the strict criterion for response that has been used $60 \%$ were well controlled on 1029 alone, and a further $18 \%$ were well controlled with a combination of 1029 and polythiazide. Included in the series were patients with all grades of idiopathic hypertension and also renal hypertension. Although none of the three patients with malignant hypertension responded to 1029 alone, the two who were subsequently treated with the combination responded well to it. Patients who had received no previous treatment responded to 1029 , and in some patients it was effective where other treatment had failed. The commonest sideeffects were postural giddiness and muscular weakness, but in only three patients did the drug have to be withdrawn because of side-effects.

We wish to thank Dr. J. H. Wright, Royal Infirmary, Glasgow, for helpful criticism and advice, and for allowing us to include his patients in this trial. We wish to thank Pfizer Limited, Sandwich, Kent, for supplies of compound 1029 and for carrying out the noradrenaline estimations. Dimethyl-phenyl piperazinieum was received through the courtesy of Dr. R. E. Bowman, research director, Parke Davis and Company, England.

\section{REFERENCES}

Crevelling, C. R., Van der Schnot, J. B., and Udenfriend, S. (1962). Biochem. biophys. Res. Commun., 8, 215.

Fife, R., Moran, F., and Prineas, J. (1962). Scot. med. 7., 7, 516

Keith, N. M., Wagener, H. P., and Barker, N. W. (1939). Amer. Ұ. med. Sci., 197, 332 .

Levine, E. Y., Levenberg, B., and Kaufman, S. (1960). F. biol. Chem., 235, 2080 .

Merrills, R. J. (1962). Nature (Lond.), 193, 988.

Merrills, R. J. (1962). Nature (Lond.), 